\title{
Strategi Guru Pendidikan Agama Islam dalam Mengembangkan Pendidikan Karakter Pada Peserta Didik
}

\author{
Samrin \\ Fakultas Tarbiyah dan Ilmu Keguruan, IAIN Kendari \\ Email: samrinsam75@yahoo.com
}

\begin{abstract}
Abstrak
Tujuan penelitian ini untuk mengungkapkan: 1) Gambaran pendidikan karakter; 2) Bentuk strategi guru PAI dalam mengembangkan pendidikan karakter. Metode yang digunakan adalah jenis kualitatif, dimana pengumpulan data dilakukan melalui dokumentasi, wawancara, dan observasi. Analisis data dilakukan melalui tahap: mengumpulkan data, mereduksi data, menyajikan data dan menyimpulkan. Untuk menguji validitas data dilakukan uji kreadibilitas, transferabilitas, dependebilitas, dan konfirmabilitas. Hasil penelitian mengungkapkan temuan: (1) gambaran dan bentuk pendidikan karakter di SMPN 5 Kendari dapat dilihat dari nilai yang dikembangkan yaitu: nilai religius, disiplin, tanggungjawab, jujur, cinta lingkungan, gemar membaca, dan kreatif. (2) strategi yang dilakukan guru PAI dalam mengembangkan pendidikan karakter yaitu: strategi tauladan, penegakkan kedisiplinan, pembiasaan, dan integritas dan internalisasi. Dari hasil peneitian, disimpulkan bahwa strategi yang dilakukan guru PAI dalam membentuk karakter yakni melalui pengintegrasian, melalui kegiatan sehari-hari yang meliputi: pemberian keteladanan, pembiasaan, teguran, nasehat, dan pengkondisian lingkungan yang menunjang pendidikan karakter. Dan yang terakhir lewat pengintegrasian yang di programkan yang berupa: kegiatan tahfidz Qur'an, pidato, dan sholat zhuhur serta ashar berjamaah. Implikasi kajian ini adalah pentingnya setiap guru PAI menjadi actor dalam pendidikan karakter di sekolah, diwujudkan dalam strategi dan program yang sistematis.
\end{abstract}

\section{Kata Kunci: Strategi Guru PAI, Pendidikan Karakter}




\title{
Strategies of Islamic Religious Education Teachers in Developing Character Education for Students
}

\author{
Samrin \\ Faculty of Tarbiyah and Teacher Training, IAIN Kendari \\ Email: samrinsam75@yahoo.com
}

\begin{abstract}
The purpose of this study is to reveal: 1) Overview of character education; 2) Form the strategy of PAI teachers in developing character education. The method used is a qualitative type, where data collection is done through documentation, interviews, and observations. Data analysis was carried out through the stages: collecting data, reducing data, presenting data and concluding. To test the validity of the data, the credibility, transferability, dependability, and confirmability tests were carried out. The results of the study reveal the findings: (1) the description and form of character education at SMPN 5 Kendari can be seen from the values developed, namely: religious values, discipline, responsibility, honesty, love for the environment, love of reading, and creativity. (2) the strategies adopted by PAI teachers in developing character education are: exemplary strategies, enforcement of discipline, habituation, and integrity and internalization. From the results of the research, it is concluded that the strategy used by PAI teachers in shaping character is through integration, through daily activities which include: giving example, habituation, reprimand, advice, and environmental conditioning that supports character education. And lastly, through the programed integration in the form of: Qur'an tahfidz activities, speeches, and congregational dhuhur and asr prayers. The implication of this study is the importance of every PAI teacher to be an actor in character education in schools, manifested in systematic strategies and programs.
\end{abstract}

Keywords: PAI Teacher Strategy, Character Education 


\section{Pendahuluan}

Kemajuan suatu bangsa terletak pada karakter yang dimiliki bangsa tersebut. Karakter merupakan hal yang sangat penting dan mendasar. Karakter adalah mustika hidup yang membedakan antara manusia dengan hewan. Manusia yang tidak berkarakter dikatakan sebagai manusia yang sudah melampui batas. Orang yang berkarakter kuat dan baik secara individual dan sosial ialah yang memiliki akhlak,moral dan budi pekerti yang baik (Zubaedi, 2011). Pandangan ini tidak hanya menunjukkan pentingnya membangun karakter bangsa, tetapi juga prosesnya dalam praktik pendidikan. Tujuan pendidikan nasional adalah simpul karakter yang diharapkan dalam proses pendidikan. Dengan itu, bangsa Indonesia akan tampil kuat sejajar dengan berbagai bangsa di dunia.

Upaya membangun karakter dapat digali dari nilai-nilai lokal, terutama dalam menciptakan perilaku yang baik dalam hubungan sosial (Fajarini, 2014). Nilai-nilai lokal dapat diajarkan pada aspek yang lebih kompleks, seperti kepemimpinan (Alim dkk, 2020). Nilainilai universal yang dianut oleh masyarakat lokal dapat menjadi muatan penting dalam proses pendidikan karakter. Meskipun demikian, pendidikan karakter mesti dikembangkan lagi pada domain yang lebih luas. Karena ada tradisi lokal yang tidak dapat menjadi energi handal untuk kemajuan. Dalam konteks ini, nilai agama, terutama nilai-nilai Islam yang bersifat mendunia, mengambil tempat dalam praktik pendidikan karakter (Pairin at al, 2019).

Dengan demikian, guru pendidikan agama Islam harus menjadi ujung tombak proses pendidikan karakter. Tidak hanya mengintegrasikan berbagai kompetensi keguruan, tetapi juga tuntutan untuk memainkan berbagai peran yang mengarah pada pembentukan karakter peserta didik (Hasba, 2019). Peran-peran keguruan yang bersifat formalistik mesti ditinggalkan, beranjak pada pemberian teladan yang baik (Munawwaroh, 2019). Selain itu, mengajak warga sekolah untuk menciptakan lingkungan sekolah yang sejalan dengan semangat pembangunan karakter (Ramdhani, 2017).

SMP Negeri 5 Kendari merupakan salah satu sekolah yang concern melaksanakan pendidikan karakter sesuai anjuran pemerintah melalui kementerian pendidikan nasional dan secara riil dilakukan oleh guru pendidikan agama Islam (PAI) SMPN 5 Kendari yang berjumlah 5 orang. Penghargaan sebagai sekolah adiwiyata dan ramah lingkungan menjadi satu indikator bahwa sekolah ini sedang dalam 
proses membangun karakter. Karenanya, penting melihat secara mendalam peran-peran guru PAI dalam pengembangan pendidikan karakter di SMP Negeri 5 Kendari.

\section{Metode}

Penelitian ini dilakukan secara kualitatif dengan pendekatan naratif (Creswell at al, 2016), sehingga data yang dihasilkan bersifat deskriptif terhadap situasi sosial yang diamati. Pengumpulan data dilakukan melalui observasi terhadap kegiatan guru PAI, kegiatan siswa, dan lingkungan SMP Negeri 5 Kendari. Wawancara dilakukan secara terstruktur dengan menggunakan pedoman wawancara. Studi dokumen dilakukan dengan cara membaca berbagai informasi sekolah yang relevan seperti: visi, misi, tujuan, dan program sekolah. Analisis data dilakukan secara bertahap, yaitu: pengumpulan data, reduksi data, penyajian data, dan verifikasi (Miles at al, 1994). Keabsahan data diuji melalui proses trianggulasi, perpanjangan pengamatan, dan peningkatan ketekunan (Sugiyono, 2011).

\section{Hasil Penelitian dan Pembahasan}

\section{A. Gambaran Pendidikan Karakter di SMPN 5 Kendari}

Gambaran dan bentuk pendidikan karekter di SMPN 5 dapat dilihat dari nilai-nilai yang telah dikembangankan, antara lain: nilai religious, disiplin, tanggung jawab, jujur, cinta lingkungan, gemar membaca, dan kreatif.

\section{A1. Nilai Religius}

Religius sebagai salah satu nilai karakter dideskripsikan sebagai sikap dan perilaku yang patuh dalam melaksanakan ajaran agama yang dianut, toleran terhadap pelaksanaan ibadah agama lain, dan hidup rukun dengan pemeluk agama lain. Siswa dalam menjalani kehidupan di lingkungan sekolah dibutuhkan karakter religius yakni menerapkan serta membiasakan siswa untuk melaksanakan ajaran Islam, diantaranya shalat dhulur berjamaah, shalat dhuha setiap hari sebelum pelajaran di mulai, dan membaca surah-surah pendek, serta yasinan di setiap hari jum'at. Hal ini dilakukan oleh seluruh komponen sekolah, karena kegiatan ini tidak mungkin terlaksana jika hanya guru PAI yang berperan.

Nilai-nilai keagamaan yang disampaikan dalam pembelajaran

PAI dapat menjadi pendukung dalam pendidikan karakter. Pembelajaran PAI mengajarkan kepercayaan kepada Allah sebagai 
fondasi agama, mengajarkan Al-qur'an dan Hadits sebagai pedoman hidup, mengajarkan fiqih untuk praktik beragama, mengajarkan sejarah sebagai contoh kehidupan, dan akhlak sebagai cara berinteraksi dengan sesame (Ainiyah dkk, 2013).

\section{A2. Disiplin}

Disiplin bukanlah sesuatu yang dibawa sejak lahir. Perkembangannya pada anak sangat dipengaruhi oleh faktor "ajar" atau pendidikan. Disiplin selalu berkaitan dengan sikap, yaitu kesediaan beraksi atau bertindak terhadap objek atau keadaan tertentu. Sikap selalu dihadapkan pada pilihan untuk menerima atau menolak, bertindak positif atau negatif. Sikap (sering disebut sikap mental) berkembang dalam proses keinginan untuk mendapatkan kepuasaan, tetapi kenyataan menunjukkan bahwa tidak semua keinginan dapat terpenuhi, karena keinginan banyak orang beraneka ragam sehingga perlu adanya peraturan, tata tertib nilai atau norma yang harus dipatuhi.

Adapun bentuk kedisiplinan yang direalisasikan di SMPN 5 Kendari adalah

a. Menaati tata tertib sekolah.

Berkaitan dengan disiplin dalam mentaati tata tertib, seorang informan mengatakan bahwa tata tertib dibuat dan disusun dengan tujuan menolong siswa menjadi lebih mandiri dan bertanggung jawab. Kedisiplinan di sekolah kaitannya dengan mentaati tata tertib pada dasarnya menjadi alat pendidikan karakter bagi pengembangan kepribadian yang lebih dewasa.

Berkenaan dengan hal tersebut, jika ada guru atau siswa yang melanggar, mereka diberi sanksi yang sifatnya mendidik. Bila ada yang melanggar berungkali, diberi sanksi yang lebih berat dan lain sebagainya.

b. Disiplin waktu

Waktu adalah suatu hal yang tidak ternilai harganya. Karena waktu merupakan masa yang berjalan, sehingga orang yang tidak memanfaatkan waktu dengan sebaik-baiknya, maka akan digilas oleh waktu.

Pemanfaatan waktu dengan sebaik-baiknya merupakan bagian yang integral dari perilaku disiplin. Oleh karena itu, disiplin waktu dalam sekolah tidak hanya bagi guru, namun juga bagi siswa. Sehingga dengan memanfaatkan waktu sebaik-baiknya, seseorang akan dapat mencapai tujuan yang diinginkan. 
Dengan demikian, dalam sekolah, pemanfaatan waktu yang kurang baik akan menganggu proses belajar mengajar. Misalnya, seorang guru yang dating terlambat mengajar, maka akan rugi terhadap waktu yang ditinggalkan. Siswa yang tidak memanfaatkan waktunya untuk belajar, maka sudah barang tentu akan ketinggalan materi yang dipelajarinya.

c. Disiplin dalam berpakaian.

Meskipun seseorang dapat memakai pakaian sesuai dengan keinginannya, namun dalam hal-hal tertentu berpakaian juga harus diatur, terutama dalam lingkungan sekolah. Melatih siswa untuk berseragam adalah mendidik untuk berdisiplin. Karena hal itu, akan menciptakan jati diri siswa yang bersih, peduli diri sendiri. Namun demikian, jika hal itu tidak ditunjang oleh guru yang berpakaian dengan baik, maka siswa juga akan sembarangan dalam berpakaian.

Berbagai kegiatan yang mendisiplinkan peserta didik dapat dilakukan dalam rangka pendidikan karakter (Utami, 2019). Tentu saja, cara ini mensyaratkan kreatifitas dan kesungguhan guru dalam mendesain berbagai kegiatan, konsisten dalam melaksanakannya, dan berkelanjutan. Mengaktifkan kegiatan kepramukaan (kepanduan) juga dapat menjadi salah satu cara yang dapat dilakukan guru (Al Azizi, 2018).

\section{A3. Tanggungjawab}

Seorang siswa yang bertanggungjawab akan menunjukkan kecintaanya pada sekolah dengan selalu berusaha disiplin, baik dalam perkataan maupun tingkah lakunya. Kesemuanya itu akan tercermin dari cara berpakaian, cara berkomunikasi dengan guru, keseriusan dalam mengikuti pelajaran, serta perilakunya yang jauh dari hal-hal negatif yang membahayakan diri dan lingkunganya.

Prestasi yang diraih serta sopan santun yang terwujud dalam perilaku, tidak hanya menbuat siswa menjadi pribadi yang disenangi teman-teman, guru, dan orang tua, tetapi juga membuatnya menjadi popular di lingkunag sekoalh. Tentunya kesempatan siswa seperti ini untuk terlibat pada kegiatan-kegiatan sangatlah besar. Ternyata pelaksanaan tanggungjawab memberi banyak keuntungan baik orang yang bersangkutan maupun orang lain.

Tanggungjawab merupakan bentuk lanjut dari hormat. Jika kita menghormati orang lain berarti kita menghargai mereka, jika menghargai mereka berarti kita merasakan sebuah ukuran dari rasa 
tanggungjawab kita untuk menghormati kesejahteraan hidup mereka. Oleh karenanya tanggungjawab merupakan pelaksanaan sebuah pekerjaan atau kewajiban dalam keluarga, di sekolah, tempat kerja dengan sepenuh hati dan memberikan yang terbaik.

Salah seorang informan mengatakan bahwa

"tanggung jawab adalah melaksanakan sebuah pekerjaan atau kewajiban yang harus dilakukan baik di dalam keluarga, di lingkungan sekolah, maupun di tempat kerja dengan sepenuh hati dan memberikan yang terbaik terhadap apa yang menjadi tanggung jawabnya."

Dengan demikian, tanggung jawab berarti kemampuan untuk merespon atau menjawab, itu artinya tanggung jawab berorientasi kepada orang lain, memberikan bentuk perhatian, dan secara aktif memberikan respons terhadap apa yang mereka inginkan. Tanggungjawab menekankan kepada kewajiban positif untuk saling melindungi satu sama lain.

Pembentukan karakter tanggungjawab bisa melalui:

a. Penanaman tanggungjawab sejak dini

b. Pemberian tata tertib sekolah

c. Pemberian tugas rumah (PR) dari sekolah

d. Pemberian tugas di rumah oleh orangtua

e. Penanaman dan melatih sikap mandiri.

f. Pembelajaran kooperatif di kelas

g. Menciptakan lingkungan kelas yang dinamis

h. Pengajaran nilai karakter tanggungjawab melalui pelajaran.

Tanggung jawab mesti diajarkan, karna berdampak pada pembentukan kepribadian, salah satunya adalah terbinanya kedisiplinan peserta didik (Suryanti dkk, 2018). Proses pembelajaran tentang tanggung jawab dapat dilakukan secara kurikuler dan ekstrakurikuler. Setiap bidang studi dapat dirancang agar terintegrasi dengan edukasi tentang tanggung jawab, misalnya dalam penerapan berbagai model pembelajaran aktif (Ardila dkk, 2017).

\section{A4. Jujur}

Kejujuran merupakan pondasi utama atas tegaknya nilai-nilai kebenaran karena jujur itu identic dengan kebenaran. Perilaku jujur dapat menghantarkan siswa yang melakukannya menuju kesuksesan dalam belajar. Jujur merupakan sikap yang tulus dalam melaksanakan sesuatu yang diamanatkan, baik berupa harta maupun tanggungjawab. 
Dalam wawancara dengan salah seorang informan, dikatakan bahwa:

"Sifat jujur dan terpercaya merupakan sesuatu hal yang sangat penting dalam segala aspek kehidupan. Kejujuran akan membuat sesorang mendapatkan cinta kasih dan keridhan Allah swt. Sedangkan kebohongan adalah kejahatan yang tiada tara, yang merupakan factor terkuat yang dapat mendorong seseorang berbuat kemunkaran dan menjerumuskannya kejurang kesesatan.”

Berdasarkan hasil wawancara di atas, maka kejujuran sebagai sumber keberhasilan, kebahagian serta ketenteraman, harus dimiliki oleh setiap siswa. Bahkan, setiap siswa wajib menamankan nilai-nilai kejujuran bukan hanya dil lingkungan sekolah tetapi diseluruh aktivitas kehidupan, karena dengan kejujuran tersebutlah yang dapat mengantarkan kesuksesan seseorang. Sedangkan kebohongan adalah sumber dari segala keburukan dan muara dari segala kecaman karena akibat yang ditimbulkannya adalah kejelekan, dan hasil akhirnya adalah kekejian.

Salah satu unsur terpenting dalam pendidikan karakter adalah kejujuran. Guru sebagai sentral dalam pendidikan di sekolah, memiliki peran yang penting dalam menanamkan nilai kejujuran pada anak. Beberapa hal yang dapat diterapkan oleh guru dalam penanaman nilai kejujuran diantaranya; melakukan pengajaran secara terus-menerus dan terintegrasi antar setiap komponen sekolah, menjadikan dirinya sebagai suri teladan bagi anak didiknya, membiasakan peserta didik untuk berperilaku jujur, melakukan refleksi diri, dan memberikan punishment kepada anak yang berperilaku tidak jujur (Amin, 2017). Pendidikan kejujuran dalam dilakukan oleh guru di kelas, melalui berbagai kegiatan kreatif yang melatih kejujuran peserta didik (Ichsan, 2019).

\section{A5. Cinta Lingkungan}

Nilai peduli lingkungan adalah suatu sikap yang ditunjukan dengan tingkat kualitas kesadaran siswa terhadap lingkungan secara umum dan lingkungan sekolah pada khususnya. Siswa mempunyai kesadaran dan tanggungjawab atas tingkat kualitas lingkungan hidup. Sikap peduli lingkungan yang dimiliki siswa bagai hasil dari proses belajar, dapat meningkatkan kepedulian siswa akan kelestarian daya dukung dari alam lingkungannya. Pada dasarnya, peduli lingkungan adalah perilaku atau perubahan manusia yang secara sadar terhadap 
lingkungan dengan dilandasi sikap tanggung jawab karena kerusakan oleh mental manusia.

Salah satu penyebab kerusakan lingkungan adalah ketamakan manusia itu sendiri terhadap lingkungan. Untuk membangun nilai peduli lingkungan sebagai dasar kesadaran merupakan hal yang sangat vital, diperlukan pribadi yang mampu mendorong meningkatkan kesadaran, yang akan timbul dengan adanya pembelajaran konsep pendidikan berkarakter.

Langkah pertama adalah dimulai dari kehidupan individu. Orang yang peduli lingkungan idealnya juga telah menerapkan kepedulian tersebut dalam kehidupannya secara pribadi. Character building dalam peduli lingkungan seyogyanya dimulai dari keluarga. Karena di dalam keluargalah seorang anak menghabiskan waktunya. Selain itu relasi emosional seperti dalam keluarga tidak ditemukan di tempat lain. Selain keluarga, peduli lingkungan juga harus ditumbuhkembangkan dalam sistem pendidikan melalui ekstrakurikuler.

Dalam praktiknya, proses edukasi peserta didik untuk mencintai lingkungan masih dilakukan dalam hal-hal sederhana, misalnya kegiatan sekolah tanpa sampah plastik (Baro'ah dkk, 2020). Hal ini nampaknya menjadi pemicu lahirnya sekolah-sekolah yang bertema alam seperti sekolah alam di Ungaran (Yudistira, 2014), ataupun program "Green and Clean" yang meliputi rogram piket bersama di kelas dan lingkungan sekitar sekolah serta belajar merawat tumbuhan yang ada di depan kelas (Liyun dkk, 2019).

\section{A6. Gemar membaca}

Membaca merupakan jendela ilmu pengetahuan, itulah ungkapan yang digunakan oleh media dahulu. Penyataan ini memang tepat, karena buku atau literatur merupakan salah satu sumber ilmu yang utama, untuk dapat menyerapnya harus dibaca. Pembudayaan membaca tentu menjadi nilai tambah positif bagi peningkatan mutu pendidikan karena dengan membaca wawasan, pengetahuan, dan pengetahuan siswa akan bertambah. Oleh karena itu, perpustakaan menjadi salah satu motor terdepan dalam upaya pembudayaan membaca. Untuk itu secara optimal, perpustakaan sekolah yang ada sekarang penting untuk dikembangkan dan dimanfaatkan.

Gemar membaca memiliki sumbangan besar dalam meningkatkan keterampilan berbahasa peserta didik (Laily dkk, 2014). Karenanya, gemar membaca menjadi salah satu pendukung dalam 
program literasi (Priasti, 2021). Karenanya penanaman nilai karakter gemar membaca penting dilakukan di tengah teralihnya perhatian peserta didik pada produk terbaru teknologi informasi dan komunikasi (Sari, 2018).

\section{A7. Kreatif}

Nilai dari pemikiran kreatif yang pertama adalah konstruktif (membangun) bukan destruktif (menghancurkan). Banyak orang memiliki ide-ide yang kreatif tetapi tidak ada yang berani mewujudkannya. Mereka kreatif tetapi tidak konstruktif. Oleh karena siswa harus dituntut untuk memiliki sifat kreatif yang konstruktif sehingga siswa tersebut memiliki kemampuan untuk membangun dalam sikap maupun pemikiran.

Nilai yang kedua dari pemikiran kreatif adalah hal itu memiliki masa depan. Sepanjang hidup, masalah pasti selalu ada. Tetapi, masalah-masalah tersebut pasti ada solusinya. Orang yang memiliki masa depan cerah adalah mereka yang memiliki kreativitas dalam memecahkan setiap masalah yang ada. Kreativitas menetukan masa depan siswa, oleh karenanya siswa perlu mengembangkan kreativitas untuk bisa berhasil dalam segala hal.

Selanjutnya, sebelum menguraikan strategi guru PAI dalam menanamkan pendidikan karakter pada siswa, terlebih dahulu, peneliti akan menguraikan terkait upaya pembinaan karakter siswa yang telah dilakukan di SMPN 5 Kendari, sebagai bagian dari gambaran pendidikan karakter di SMPN 5 kendari.

Pembinaan karakter di sekolah sangat diperlukan dalam mengembangkan karakter positif sehingga siswa dapat bersikap dan bertingkah laku sesuai dengan norma-norma, etika, dan kesusilaan yang ada dalam masyarakat. Melalui pembinaan karakter di sekolah, siswa dibina, dibentuk, diarahkan dan dibimbing untuk memiliki karakter yang baik sehingga dirinya dapat menunjukkan sikap atau prilaku yang baik ketika berkomunikasi dengan orang lain maupun dengan masyarakat lainnya.

Kemampuan mencipta menjadi kelemahan dalam ouput pendidikan kita. Hal ini berbanding lurus dengan perilaku menyontek dan plagiasi. Hal ini menunjukkan penurunan kualitas moral anak bangsa, sehingga tidak dapat berkompetisi dalam skala yang lebih luas (Angelia, 2019). Pembinaan kepercayaan diri sangat dibutuhkan, terutama untuk menjadi insan kreatif (Shara, 2017). 


\section{B. Strategi Guru PAI dalam Pengembangan Pendidikan Karakter Pembahasan}

Strategi yang dilakukan Guru PAI di SMPN 5 Kendari antara lain: Tauladan, penegakan disiplin, pembiasaan, integritas dan internalisasi.

\section{B1. Tauladan}

Strategi ini merupakan pendidikan dengan memberi contoh, baik berupa tingkah laku, maupun lisan. Keteladaan merupakan ilmu pendidikan yang menentukan keberhasilan dalam membentuk sikap, perilaku, moral, spiritual dan sosial anak, karena dengan memberi contoh yang baik, maka akan menghasilkan siswa yang berkarekter. Misalnya guru PAI menjadi contoh dalam mematuhi semua peraturan akademik yang berlaku di sekolah. Sebagaimana pernyataan informan kepada peneliti, dikatakan bahwa:

"Untuk mengawali pembentukan dan penerapan nilai-nilai pendidikan karaktek di sekolah ini, dimulai ketika diadakan masa orientasi sekolah (MOS), pada kegiatan tersebut sudah diperkenalkan peraturan yang ada di sekolah. Pada kegiatan MOS ini dibentuk kepanitian dari siswa itu sendiri."

Dari paparan di atas, dapat dipahami bahwa pembentukan pendidikan karakter kepada siswa SMPN 5 Kendari diawali dari masa orientasi sekolah (MOS) di sekolah, pada saat iltulah seorang guru PAI bias memperkenalkan peraturan dan tanggungjawab siswa ketika berada di sekolah, hal-hal yang harus diteladani siswa baik cara berkomunikasi dengan guru, dengan siswa dan sebagainya.

Sebagaimana yang dipahami bahwa pada masa orientasi inilah siswa akan mulai berfikir sehingga menjadi tahu apa yang harus dilakukan. Selebihnya dari itu tugas dari kakak panitia yang akan membuat siswa mulai latihan dan berlatih untuk memtaati peraturan dan enjalankan tanggungjawabnya, mulai dari disiplin dan sebagainya. Dengan adanya kepanitian ini juga bisa menjadikan jembatan untuk memperkenalkan, melatih, memotivasi, bisa menjaga dan mendampingi adik-adiknya untuk berkreasi dan belajar mengenal lebih jauh terhadap lingkungan sekolah.

Demikian halnya yang dikatakan salah seorang informan bahwa keteladanan itu sangat penting untuk pembentukan pendidikan karakter pada siswa, sebagaimana hasil wawancara berikut:

"Dalam proses pembelajaran serta pelaksanaan praktek terhadap materi yang disampaikan, seorang guru harus membaur dengan 
siswa, misalnya dalam pelaksanaan berwudhu guru sebagai contoh atau ikutan yang akan dipraktekkan langsung oleh siswa. Di samping itu juga bagaimana sikap seorang guru kepada siswa dihadapan siswa yang lain, sehingga siswa juga akan menjaga sikapnya terhadap guru".

Dari pemaparan informan tersebut di atas, bahwa, dalam membaur bersama siswa tidak terbatas waktu dan tempat, karena dengan demikian guru bias memberikan contoh suritauladan mulai dari mempraktekkan cara berwudhu yang baik dan benar, dalam bertutur bahasa antara siswa dengan guru dan siswa dengan siswa, begitu juga bagaimana bersikap guru dengan siswa ataupun sebaliknya, sehingga siswa akan berusaha menjaga dan melatih diri untuk lebih baik.

Sesuai dengan pemaparan di atas, dapat dipahami bahwa dalam memberikan contoh terhadap siswa berawal dari guru itu sendiri, kemudian membenahi siswa sesuai dengan guru PAI contohkan yang dalam hal ini bagaimana cara berpakaian dan menggunkan jilbab yang benar. Oleh karenanya suritauladan yang benar yakni sesuai dengan konsep Rasulullah adalah memberikan contoh bukan memberikan arahan dan teguran saja, akan tetapi yang terpenting adalah berangkat dari seorang guru itu sendiri yang kemudian dijadikan contoh untuk siswanya dari segi apapun.

Selanjutnya, komunikasi dan tuturkata perlu juga dijaga, karena dalam pepatah dikatakan bahwa tergelincirnya kaki itu lebih selamat dari pada tergelincirnya lisan, maka dari itu sangat penting bagi seorang guru untuk selalu menjaga tuturkata dari dirinya sendiri kemudian untuk menegur dan memberikan arahan bagaimanaan bertuturkata yang baik, baik untuk teman sebaya di sekolah maupun dilingkungannya di mana ia tinggal, lebih terhadap guru dan orang tua di rumah.

Keteladanan merupakan salah satu metode dalam pendidikan karakter (Munawwaroh, 2019). Dalam hal ini guru merupakan sarana atau model dalam keteladanan (Sutisna dkk, 2019). Tidak hanya pada sosok guru, tetapi dapat juga dikembangkan pada figure-figur dalam sejarah nasional ataupun sejarah dunia, yang memiliki jasa besar dalam kemanusiaan (Setianto, 2019). Caranya dapat diintegrasikan dalam pembelajaran sejarah, atau melalui media teknologi yang dapat mengenalkan figure-figur sejarah tersebut, sehingga peserta didik dapat mengenal mereka dengan baik. 


\section{B2. Penegakan kedisiplinan}

Dalam melaksanakan penegakan kedisiplinan, guru PAI bapak Hatta memaparkan, sebagai berikut:

"Terkait kedisiplinan itu sangat banyak, untuk itu lebih fokus terkait dengan strategi guru PAI di sekolah, pertama merancang peraturan, kemudian peraturan itu ditempel dan disampaikan kepada siswa, setelah itu saya (guruPAI) dan guru-guru yang lain juga menjaga peraturan itu, mengontrol siswa, kalau ada yang melanggar langsung ditindaki dengan memberikan teguran dan dinasehati, jika melanggar lagi maka siswa tersebut akan diberikan hukuman sesuai tingkat pelanggaran yang dilakukan".

Berdasarkan uraian di atas, penulis menyimpulkan bahwa guru PAI dalam menegakkan kedisiplinan di sekolah adalah dengan membuat berbagai peraturan sekolah dan untuk mengontrol peraturan tersebut dikerahkan atau melibatkan seluruh stakeholder di sekolah, adapun bagi siswa yang melanggar akan diberikan teguran dan dinasehari dan jika pelanggaran tersebut berulang-ulang maka guru akan memberikan konsekuensi dari pelanggaran yang dilakukannya.

Selanjutnya, dalam upaya mendisiplinkan siswa seorang guru PAI harus melakukan kebijaksanaan berupa sanksi yang mendidik kepada peserta didiknya agar peserta didik tersebut tumbuh memiliki rasa kesadaran bahwa apa yang dilakukannya tidak benar dan tidak akan mengulanginya lagi. Dan sanksi yang diberikan tersebut harus berupa sanksi yang mendidik.

Beberapa upaya harus segera dilakukan oleh sekolah dalam upaya mendisiplinkan siswa sehingga mereka memiliki perilaku yang baik dan berprestasi. Salah seorang informan, mengatakan bahwa:

"Yang ditekankan disini terkait dengan kejujuran, kedisiplinan, cinta lingkungan, saling kenal mengenal, demokrasi, kreatifitas dan bekerja keras. Untuk kedisiplinan dalam pembelajaran, khususnya di kelas, ketika ada siswa yang tidak tertib, tidak fokus dan suka usil, maka saya mencoba untuk mengingatkan dan menegurnya serta memberi peringatan".

Sesuai dengan apa yang dikemukakan informan tersebut di atas, dapat dipahami bahwa dengan problem yang ada, seorang guru PAI memulai dengan mengingatkan, menegur dan memberi peringatan kepada siswa bahwa hal yang demikian itu tidak baik, sudah jelas bahwa suri tauladan yang baik dan menjadi seorang guru yang bijaksana juga tidak langsung memberikan konsekuensi kepada 
siswa melainkan terlebih dahulu memberikan nasehat, berupa teguran, peringatan hingga menuntun kepada yang seharusnya siswa lakukan tentunya diarahkan kepada hal yang baik.

"Ketika siswa masih saja melakukan kebiasaannya, maka saya selaku guru PAI akan mengambil tindakan yakni memberikan hukuman dengan memindahkan siswa tersebut ke kelas yang lain, ketika siswa itu menjawab tidak siap, maka ditanya lagi untuk kesiapannya untuk tertib di kelasnya yang semula, dengan demikian barulah siswa tersebut dikembalikan ke kelasnya".

Dengan penegasan tersebut di atas, dapat dipahami bahwa, seorang guru tentunya mempunyai banyak cara untuk mendidik anak didiknya, salah satunya dalam memberikan konsekuensi kepada siswa, dengan demikian siswa mampu membedakan mana yang baik dan mana yang tidak baik. Berdasarkan paparan informan, menurut penulis ini sangat menarik ketika seorang guru memberikan konsekuensi kepada siswa berupa perbandingan tenpat dalam belajar, karena dapat dipastikan bahwa siswa akan merasa tidak enak ketika dibarengkan dengan siswa lain dengan kakak tingkatnya, apalagi dengan pelajaran yang belum diketahuinya. Maka dari , siswa akan sadar dengan kesalahannya dan bisa menjadikannya untuk tidak mengulangi kesalahan yang sama.

Beda lagi dengan siswa-siswi yang tidak disiplin di lingkungan sekolah, misalnya siswa tersebut menempatkan buku yang telah dibaca bukan pada tempatnya, maka selain dengan peringatan, dia juga akan diberikan konsekuensi dari perbuatannya berupa merapikan semua buku-buku yang telah dibaca oleh teman-temannya yang lain.

Lebih lanjut Hatta memaparkan terkait dengan strategi penanaman nilai-nilai karakter pada peserta didik di SMPN 5 Kendari, bahwa

"Dengan strategi kedisiplinan yang diterapkan di lingkungan sekolah di antaranya penerapan aturan-aturan di perpustakaan, yakni bagi yang melanggar maka akan selalu diberikan konsekuensi yang sesuai dengan kesalahan siswa itu sendiri, maka hal ini akan berdampak pada karekter siswa yang akan selalu disiplin terhadap peraturan-praturan di lingkungan sekolah".

Sebagai sesorang guru yang selalu diguguh dan ditiru, maka selayaknya guru dalam mengajarkan siswanya diawali dari dirinya sendiri, sehingga bisa ditiru oleh siswanya, dalam konsep suritauladan 
yang baik itu adalah bukan serta merta memerintahkan siswanya untuk berbuat dan melakukan sesuatu, akan tetapi seorang guru lebih tepat untuk memberikan contoh kemudian mengajar siswanya untuk menirukan apa yang dilakukan gurunya. Sebagaimana yang dikatakan salah satu informan bahwa:

"Seorang guru haruslah memberikan contoh kepada siswanya, guru tidak hanya memerintahkan kepada siswa akan tetapi guru terlebih dahulu memberikan contoh, misalnya terkait dengan kebersihan lingkungan sekolah, jika ada sampah maka seorang guru itu yang mengambilnya terlebih dahulu dan menaruh ditempat sampah, dengan demikian siswa secara tidak langsung akan menirukan apa yang dilakukan guru tersebut".

Demikian halnya dalam dalam kegiatan yang lain, sebagaimana yang dikatakan seorang informan bahwa:

"Terkait dengan tempat ibadah, jika terdapat siswa yang melanggar peraturan, maka juga disiapkan konsekuensi dari pelanggaran yang dilakukan, yakni pertama diingatkan, kedua diberi nasehat dan yang ketiga diberi konsekuensi terhadap pelanggarannya dengan membersihkan tempat berwudhu, kalau masih melanggar lagi maka akan diberikan hukuman yang lebih dari sebelumnya, sampai siswa menyadari dirinya dan tidak mengulangi pelanggarannya".

Penegasan di atas dapat disimpulkan bahwa starategi guru PAI sangat jelas dalam mengingatkan siswa dan mengarahkan ataupun memberikan peringatan, di samping itu juga perkataan yang membuat siswa akan malu dengan sendirinya setelah mendapatkan peringatan keras dar seorang guru. Terkadang memang seorang siswa masih tetap kokoh dengan kebiasaan yang di bawah dari lingkungannya di masyarakat ke sekolah, sehingga menjadi sulit untuk dirubah, akan tetapi bagi seorang guru PAI membuat seorang siswa berubah banyak startegi atau cara yang bisa dilakukan.

Penegakan disiplin dapat menjadi salah satu cara dalam penerapan pendidikan karakter (Hastuti, 2012). Dalam prosesnya, beberapa sekolah menindaklanjuti dalam bentuk reward and punishment, sebagai bentuk penguatan pendidikan karakter (Rizkita dkk, 2020). Namun demikian, karena terkait dengan pembinaan SDM, maka factor kepemimpinan menjadi kuncinya, sebagaimana diterapkan pada sekolah-sekolah berasrama, seperti PM Gontor (Mukhtar at al, 2019). 


\section{B3. Pembiasaan}

Menurut Mulyasa strategi pembiasaan merupakan metode yang paling tua, beliau mengartikan pembiasaan adalah sesuatu yang secara sengaja dilakukan berulang-ulang agar sesuatu yang akan ia capai itu dapat menjadi kebiasaan (Mulyasa, 2011). Dalam bidang psikolgi pendidikan, strategi pembiasaan di kenal dengan istilah operant conditioning. Pembiasaan akan menbangkitkan internalisasi nilai dengan cepat sehingga upaya menghayati dan mendalami nilai akan tertanam dalam diri manusia, karenanya karakter berorientasi pada pendidikan nilai, sehingga perlu adanya internalisasi tersebut. Dalam strategi pembiasaan ini, terdapat dua hal yang harus dibiasakan yakni, pertama guru menerapkan $3 \mathrm{~S}$ (senyum, sapa dan salam).

Berdasarkan apa yang disampaikan salah seorang guru PAI dan kepala sekolah SMPN 5 Kendari, maka dapat dipahami bahwa peran guru PAI khususnya dan peran semua guru pada umumnya dalam membentuk karakter siswa, di mulai sejak siswa datang ke sekolah di pagi hari sampai siswa itu pulang meninggalkan sekolah. Para guru yang khususnya yang memiliki jam mengajar dipagi hari atau guru yang bertepatan mendapatkan jadwal piket, sebelum jam masuk, guru berdiri di depan kelas untuk membiasakan menerapkan 3 $\mathrm{S}$ (senyum, sapa, salam) dalam upaya pembentukan karakter siswa di SMPN 5 Kendari.

Pembentukan karakter siswa perlu diwujudkan dalam lingkungan keluarga, masyarakat dan di lingkungan sekolah secara berkesinambungan. Pelaksanaan pendidikan karakter di sekolah perlu didukung oleh peran keluarga khususnya orang tua juga peran masyarakat atau lingkungan sekitar di mana siswa itu tinggal.

Oleh karena itu, sekolah sebagai pelaksana pendidikan formal perlu memperhatikan elemen-elemen yang ada di dalamnya dalam mengintegrasikan semua aspek untuk menanamkan pendidikan karekter pada peserta didik, bukan semata dari segi akademiknya saja namun dimensi akhlak dan karakter merupakan hal yang utama. Percuma saja jika sekolah setiap tahun meluluskan lulusan yang IQ di atas rata-rata namun tidak debarengi dengan karakter yang baik dan akhlak yang mulia. Karena sudah banyak orang pintar dimasyarakat yang tidak memiliki karakter yang baik sehingga perbuatannya merugikan diri sendiri, masyarakat bahkan merugikan negara. 
Kedua, membiasakan kepada siswa untuk melaksanakan program-program keagamaan dan ibadah rutin, dalam wawancara dengan salah seorang informan, dikatakan bahwa:

"Selama ini sekolah telah menerapkan banyak program yang bisa membentuk karakter siswa di SMPN 5 Kendari, di antaranya shalat dhuha tiap pagi yang diikuti oleh semua siswa dan para guru, mengaji/menbaca yasinan yang dilaksanakan pada hari jum'at, membaca surat-surat pendek setiap hari rabu dan hari kamis, serta shalat dzuhur berjamaah setiap hari yang diikuti seluruh siswa dan guru. Dalam kegiatan ini, tidak hanya guru PAI yang berperan, namun melibatkan semua guru. Dengan demikian, siswa secara tidak langsung meneladani guru-gurunya".

Berdasarkan pemaparan informan tersebut di atas, dapat disimpulkan bahwa strategi-strategi yang diterapkan oleh guru PAI pada khususnya maupun sekolah dalam hal in SMPN 5 Kendari pada umumnya sudah mengupayakan sekuat tenaga untuk menanamkan nilai-nilai karakter yang Islami seperti shalat dhuha, shalat dzuhur berjamaah, yasinan, membaca surat-surat pendek dan lainnya.

Diharapkan dari pembiasaan program-program keagamaan tersebut walaupun sifatnya paksaan untuk siswa, namun dengan paksaan tersebut akan berubah menjadi kebiasaan. Sehingga yang tadinya siswa itu terpaksa melaksanakan shalat dhuha contohnya, kemudian karena keharusan dan terus menerus (continue) dengan maka akan sendirinya berubah menjadi kebiasaan yang jika tidak dilaksanakan perbuatan tersebut akan merasa tidak enak atau ada sesuatu yang mengganjal dihati siswa.

Salah seorang informan menegaskan kembali dengan pembiasaan untuk peserta didik di sekolah, sebagai berikut:

"Di sekolah ini selalu dibiasakan pelaksanaan perayaan hari-hari besar Islam (PHBI), misalnya peringatan maulid Nabi, Isra' mi'radj, dan peringatan tahun baru Islam 1 Muharram, serta halal bihalal. Selain itu juga, dilaksanakan perayaan hari-hari besar Nasional".

Dapat disimpulkan bahwa di sekolah ini selain melakukan pembiasaan yang sifatnya umum seperti pembiasaan dan penerapan 3 $\mathrm{S}$ (senyum, sapa, salam) dan kegiatan-kegiatan yang lain, pembiasaan nilai-nilai karakter ini sangatlah penting untuk generasi muda muslim saat ini, tanpa disadari keyakinan dan pengetahuan terhadap nilai-nilai keislaman semakin menipis, jadi sangat menarik sekali ketika sekolah 
umum seperti SMPN 5 Kendari untuk bisa mengedepankan kegiatankegiatan keislamaan.

Oleh karena itu, pembiasaan merupakan suatu kegiatan latihan yang terus menerus agar terbentuk mental dan karakter pada peserta didik. Dengan pembiasaan tersebut peserta didik akan terlatih dan terbiasa melakukan kegiatan dengan baik tanpa adanya paksaan. Pembiasaan merupakan kegiatan yang berfungsi sebagai salah satu strategi yang bisa digunakan guru PAI di sekolah. Pembiasaan merupakan metode dalam pendidikan karakter (Hendriana dkk, 2017). Praktik-praktis pembiasaan ini secara konsisten dapat dilihat dalam kehidupan pesantren, dilakukan selama 24 jam, mulai dari hal-hal sederhana hingga yang lebih besar (Hidayat, 2015).

\section{B4. Integritas dan internalisasi}

Salah satu strategi yang juga dilakukan guru PAI dalam pembentukan pendidikan karakter pada siswa SMPN 5 Kendari adalah integritas dan internalisasi. Integritas dan internalisasi dalam hal ini, guru PAI melibatkan banyak elemen intern sekolah dan ekstern, di antaranya adalah dewan guru, staf Tata Usaha (TU), termasuk clening service, selebihnya sekolah juga bekerjasama dengan wali siswa, karena wali siswa dianggap sangat berpengaruh untuk membantu guru PAI dalam membentuk karakter siswa. Salah satu contoh penerapan integritas dan internalisasi pada diri siswa adalah sebagaimana yang dikemukakan salah seorang siswa sebagai berikut:

"Untuk keindahan lingkungan sekolah, setiap hari sabtu dilakukan kegiatan PRAMUKA, melalui kegiatan ekstra ini juga kami (siswa) diajarkan bagaimana mencintai lingkungan, dalam hal ini melalui kegiatan pramuka, dengan demikian kami akan memiliki tanggungjawab dalam melestarikan lingkungan sekolah”.

Berdasarkan keterangan di atas, dapat dipahami betapa luasnya dan banyaknya startegi dari seorang guru untuk mengaplikasikan nilai-nilai pendidikan karekter kepada siswa, dan seorang guru PAI bisa memanfaatkan berbagai cara melalui kegiatan ekstrakurikuler, misalnya kegiatan kepramukaan, karena dalam kepramukaan itu juga terkandung nilai-nilai karakter, salah satunya adalah yang tertera dalam kode etek ayat kedua yang berbunyi cinta alam dan kasih sayang kepada sesama manusia.

Dengan demikian, dapat disimplulkan bahwa strategi guru PAI dalam pembentukan karakter siswa melalui pendidikan dapat 
dilakukan dengan pengintegrasian dan pembelajaran. Strategi yang dilakukan untuk pembentukan karakter yaitu melalui kegiatankegiatan eksrakurikuler seperti kegiatan TPQ, tahfidz Quran, ceramah (kultum), seni, dan juga membaca surah-surah pendek, sholat dzuhur dan ashar berjama'ah. Dan ini terus-menerus dilakukan setiap hari agar guru dan siswa terbiasa dan agar lebih peka terhadap kegiatankegiatan yang nilai-nilai islam.

Dan yang kedua, pengintegrasian lewat kegiatan sehari-hari yang berupa pemberian keteladanan seperti teguran, nasehat, pengkondisian lingkungan yang menunjang pendidikan karakter, kegiatan rutin, pembiasaan karakter, dan kegiatan pendampingan dan pengawasan pendidikan karakter. Ketiga, lewat pembelajaran harus sudah menerapkan pembelajaran karakter yang meliputi rencana dan perangkat pembelajaran yang memuat nilai-nilai karakter, pelaksanaan yang menggunakan metode yang dapat membentuk karakter serta eveluasi dan tindak lanjut yang memuat nilai-nilai berdasarkan karakter.

Guru tidak dapat bekerja sendiri dalam membangun karakter peserta didik. Karenanya dibutuhkan keterlibatan komponenkomponen sekolah, seperti pimpinan dan tenaga kependidikan (Hadiyanto, 2018). Pada saat yang sama orang tua dan masyarakat mesti terlibat dalam membangun karakter peserta didik (Sari dkk, 2018).

\section{Kesimpulan dan Implikasi}

Pendidikan karakter merupakan upaya membangun kepribadian peserta didik secara paripurna, kuat secara psikis dan tangguh menghadapi tantangan zaman. Mengenalkan nilai-nilai religious, disiplin, tanggung jawab, jujur, cinta lingkungan, gemar membaca, dan kreatif, adalah ragam model yang dapat diterapkan. Sementara itu, guru sebagai ujung tombak pendidikan karakter mesti mengembangkan kreatifitas dalam menjalankan perannya dalam membangun karakter peserta didik. Keteladanan, penegakan disiplin, pembiasaan, tanggung jawab, dan proses integrasi dapat menjadi cara guru dalam pendidikan karakter. Sebagai proses edukasi, sangat terbuka kemungkinan untuk menghadirkan strategi baru yang lebih efektif dalam pendidikan karakter. Karena itu, disarankan perlu penelitian pengembangan model pendidikan karakter yang efektif di era 4.0. 


\section{Daftar Pustaka}

Al Azizi, N. Q. U. (2018). Kegiatan ekstrakurikuler kepramukaan terhadap pendidikan karakter kedisiplinan. Jurnal Pendidikan Luar Sekolah, 12(2), 40-50.

Alim, N., Badarwan, B., \& Syahrul, S. (2020). Edukasi Kepemimpinan Berbasis Tradisi Lokal pada Masyarakat Tolaki di Kabupaten Konawe. Shautut Tarbiyah, 26(1), 32-49.

Ainiyah, N., \& Wibawa, N. H. H. P. (2013). Pembentukan karakter melalui pendidikan agama Islam. Al-Ulum, 13(1), 25-38.

Amin, M. (2017). Peran Guru Dalam Menanamkan Nilai Kejujuran Pada Lembaga Pendidikan. TADBIR: Jurnal Studi Manajemen Pendidikan, 1(1), 105-124.

Angelia, I. (2019). Menyontek Sebagai Bagian Dari Dekadensi Moral Bangsa. Journal of Civic Education, 2(2), 120-125.

Ardila, R. M., Nurhasanah, N., \& Salimi, M. (2017, October). Pendidikan Karakter Tanggung Jawab dan Pembelajarannya di Sekolah. In Prosiding Seminar Nasional Inovasi Pendidikan.

Baro'ah, S., \& Qonita, S. M. (2020). Penanaman CiLi (Cinta Lingkungan) Pada Siswa Melalui Program Lingkungan Sekolah Tanpa Sampah Plastik. JURNAL PANCAR (Pendidik Anak Cerdas dan Pintar), 4(1).

Creswell, J. W., \& Poth, C. N. (2016). Qualitative inquiry and research design: Choosing among five approaches. Sage publications.

Fajarini, U. (2014). Peranan kearifan lokal dalam pendidikan karakter. SOSIO-DIDAKTIKA: Social Science Education Journal, 1(2), 123-130.

Hadiyanto, H. (2018). Pelibatan Manajemen dan Stakeholder Sekolah dalam Penguatan Pendidikan Karakter di Era Global.

Hasba, S. (2019). Multi Peran Guru di SMP Negeri 1 Konawe Selatan (Antara Kinerja dan Panggilan Moral). Shautut Tarbiyah, 25(2), 359-378.

HASTUTI, W. T. (2012). Penegakan Kedisiplinan Dalam Rangka Implementasi Pendidikan Karakter Siswa Di Sekolah (Studi Kasus Di Smp Negeri 4 Tawang Sari, Kecamatan Tawang Sari, Kabupaten Sukoharjo) (Doctoral dissertation, Universitas Muhammadiyah Surakarta). 
Hendriana, E. C., \& Jacobus, A. (2017). Implementasi pendidikan karakter di sekolah melalui keteladanan dan pembiasaan. JPDI (Jurnal Pendidikan Dasar Indonesia), 1(2), 25-29.

Hidayat, N. (2015). Implementasi Pendidikan Karakter Melalui Pembiasaan Di Pondok Pesantren Pabelan. Jurnal Pendidikan Sekolah Dasar Ahmad Dahlan, 2(1), 95-106.

Ichsan, I. (2019). Pendidikan nilai kejujuran berbasis kelas di madrasah ibtidaiyah negeri 1 bantul yogyakarta. Edukasia: Jurnal Penelitian Pendidikan Islam, 14(1), 49-70.

Jamal, Ma'mur Asmani. Buku Panduan Internalisasi Pendidikan Karakter di Sekolah. Yogyakarta: Diva Pres, 2011.

Laily, I. F., \& Naqiyyah, M. (2014). Kontribusi penerapan pendidikan karakter (gemar membaca) terhadap keterampilan berbahasa siswa pada mata pelajaran Bahasa Indonesia kelas V MI Darul Hikam Cirebon. Al Ibtida: Jurnal Pendidikan Guru MI, 1(2).

Liyun, N., Khasanah, W. N., \& Tsuraya, N. A. (2019). MENANAMKAN KARAKTER CINTA LINGKUNGAN PADA ANAK MELALUI PROGRAM "GREEN AND CLEAN". KoPeN: Konferensi Pendidikan Nasional, 1(1), 136140.

Miles, M. B., \& Huberman, A. M. (1994). Qualitative data analysis: An expanded sourcebook. sage.

Mukhtar, M., \& Akbar, M. (2019, December). Kiai's Leadership in Managing Human Resources. In 3rd International Conference on Education Innovation (ICEI 2019) (pp. 79-82). Atlantis Press.

Mulyasa, H. E. (2016). Manajemen pendidikan karakter.

Munawwaroh, A. (2019). Keteladanan Sebagai Metode Pendidikan Karakter. Jurnal Penelitian Pendidikan Islam,[SL], 7(2), 141156.

Pairin, P., Badarwan, B., \& Syahrul, S. (2019). Grand Design of Character Education Based on Islamic Values.

Priasti, S. N., \& Suyatno, S. (2021). Penerapan Pendidikan Karakter Gemar Membaca Melalui Program Literasi di Sekolah Dasar. Jurnal Kependidikan: Jurnal Hasil Penelitian dan Kajian Kepustakaan di Bidang Pendidikan, Pengajaran dan Pembelajaran, 7(2), 395-407.

Ramdhani, M. A. (2017). Lingkungan pendidikan dalam implementasi pendidikan karakter. Jurnal Pendidikan UNIGA, 8(1), 28-37. 
Rizkita, K., \& Saputra, B. R. (2020). Bentuk Penguatan Pendidikan Karakter pada Peserta Didik dengan Penerapan Reward dan Punishment. Pedagogi: Jurnal Ilmu Pendidikan, 20(2), 10-14.

Sari, P. P. (2018). Penanaman Nilai Karakter Gemar Membaca. Jurnal Ilmiah Mahasiswa Raushan Fikr, 7(2), 205-217.

Sari, Y. Y., \& Kosasih, A. (2018). MODEL PELIBATAN ORANG TUA DALAM PENDIDIKAN KARAKTER DI LEMBAGA PENDIDIKAN ANAK USIA DINI. In Prosiding Seminar Nasional Berseri (pp. 394-411).

Setianto, Y. (2019). Pendidikan Karakter Melalui Keteladanan Pahlawan Nasional. Publikasi Pendidikan, 9(2), 177-186.

Shara, S. (2017). Hubungan Self-efficacy Dan Perilaku Menyontek (Cheating) Pada Mahasiswa Fakultas Psikologi Universitas X. Jurnal Psikologi, 9(1).

Sugiyono, P. (2011). Metodologi penelitian kuantitatif kualitatif dan R\&D. Alpabeta, Bandung.

Suryanti, I., \& Arafat, Y. (2018). Implementasi Pendidikan Karakter Disiplin dan Tanggung Jawab di SD Negeri 18 Air Kumbang. JMKSP (Jurnal Manajemen, Kepemimpinan, dan Supervisi Pendidikan), 3(2), 200-206.

Sutisna, D., Indraswati, D., \& Sobri, M. (2019). Keteladanan Guru sebagai Sarana Penerapan Pendidikan Karakter Siswa. JPDI (Jurnal Pendidikan Dasar Indonesia), 4(2), 29-33.

Utami, S. W. (2019). Penerapan Pendidikan Karakter Melalui Kegiatan Kedisiplinan Siswa. Jurnal Pendidikan, 4(1), 63-66.

Yudistira, C. (2014). Implementasi Pendidikan Karakter Peduli Lingkungan di Sekolah Alam Ungaran Kabupaten Semarang (Doctoral dissertation, Universitas Negeri Semarang).

Zubaedi, D. P. K. (2011). Konsepsi dan Aplikasinya dalam Lembaga Pendidikan. Jakarta: Kencana. 